\title{
Between prophecies and prognoses: Januário da Cunha Barbosa, slavery, and the future of the nation (1830-1836) ${ }^{1}$
}

\author{
Danilo José Zioni Ferretti[1]
}

\begin{abstract}
This article aims at understanding the role played by the discussions about slavery and slave trafficking in the literate culture of Brazil in the 19th century, especially regarding the forms offiguring out the future of the nation. The way Canon Januário da Cunha Barbosa, an important politician and an illustrated intellectual, related projections of the future of the nation and treated the slavery issue (from 1830 to 1836) is analyzed. We discuss the use of projection modalities: prophecy and prognosis. Through them, Januário was involved in political discussions regarding the end of slave trafficking, and made political use of the Malê Revolt and Haitianism. The constitution of a horizon of antislavery expectation is indicated by the Canon, which is seen as one of the reasons to create the Brazilian Historic and Geographic Institute (1838). Keywords: intellectuals; slavery; temporality.
\end{abstract}

Entre profecias e prognósticos: Januário da Cunha Barbosa, a escravidão e o futuro da nação (1830-1836)

\section{Resumo}

Neste artigo, busca-se compreender o papel que o embate em torno da escravidão e do tráfico de escravos desempenhou na cultura letrada oitocentista brasileira, com destaque para as formas de imaginar a nação. Analisa-se a forma como o Cônego Januário da Cunha Barbosa, importante político e intelectual ilustrado, relacionava projeções de futuro nacional e tratamento da questão da escravidão, entre os anos de 1830 e 1836. Discute-se o uso de duas modalidades de projeção de futuro: a profecia e o prognóstico. Por meio delas, Januário envolveu-se nos embates políticos em torno do fim do tráfico de escravos e fez uso político da revolta dos malês e do haitianismo. Indica-se a constituição de um horizonte de expectativa antiescravista pelo Cônego, entendido como uma das condições para a criação do Instituto Histórico e Geográfico Brasileiro (1838).

Palavras-chave: intelectuais; escravidão; temporalidade.

Entre profecías y pronósticos: Januário da Cunha Barbosa, la esclavitud y el futuro de la nación (1830-1836)

\section{Resumen}

En este artículo, tratamos de comprender el rol que la lucha contra la esclavitud y la trata de esclavos jugó en la cultura literaria brasileña del siglo 19, destacando las formas de imaginar a la nación. Analizamos cómo el canónigo Januário da Cunha Barbosa, importante político y intelectual ilustrado, relacionaba las proyecciones de futuro nacional y el abordaje de la cuestión de la esclavitud, entre los años 1830 y 1836. Se discute el uso de dos modalidades de proyección de futuro: la profecía y el pronóstico. Por intermedio de ellos, Januário se involucró en las luchas políticas en torno al final de la trata de esclavos y hizo uso político de la rebelión de los "malês" y del haitianismo. Indicamos la formación de un horizonte de expectativa antiesclavista por el canónigo, comprendido como una de las condiciones para la creación del Instituto Histórico y Geográfico Brasileño (1838).

Palabras clave: intelectuales; esclavitud; temporalidad.

Entre própheties et pronostics: Januário da Cunha Barbosa, l'esclavage et l'avenir de la nation (1830-1836)

Résumé

Cet article cherche à comprendre le rôle du débat sur l'esclavage et le trafic d'esclaves dans la culture érudite du dix-neuvième siècle au Brésil, notamment les façons d'imaginer la nation. On examine la manière comme le chanoine Januário da Cunha Barbosa, un important homme politique et intelectuel, se référaient à les projections de l'avenir de la nation devant la question de l'esclavage entre 1830 et 1836. On discute l'usage de deux façons de se projeter vers l'avenir: la prophétie et le pronostic. Avec ces vues, Januário s’a impliqué dans chocs politiques sur la fin du trafic d'esclaves et a usé la revolte des malês et l'haitianisme. On indique une expectative anti-esclavage par le chanoine, considérée une des conditions pour la création de l'Institute Historique et Geographique du Brésil (1838).

Mots-clés: les intellectuels; esclavage; temporalité.

Article received on February 4, 2014 and approved for publication on September 29, 2014

[1] Department of Social Sciences at Universidade Federal de São João del-Rei (UFSJ) - São João del-Rei (MG) - Brazil. E-mail: daniloferretti@oi.com.br

'This article is a result of the research financed by Minas Gerais Research Foundation (FAPEMIG - Universal Edict 2008).

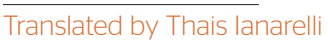


$\mathrm{R}$ ecent studies have questioned the existence of a proslavery consensus among Brazilian elites in the early $19^{\text {th }}$ century, indicating the existence of a public debate about slavery and slave trafficking with strong impact on the political community. ${ }^{2}$ Here, I try to understand how the politicization of slavery was related to the literate culture in 19th century Brazil. More specifically, it is worth questioning if slavery would have influenced the way intellectuals imagined the future Brazilian nation. ${ }^{3}$ Theoretically, I believe that the reflection about the nation in 19th-century Brazil must consider the temporal dimension of forms it was expected to adopt, with different projections in its indissociable relationship from the analysis of past experiences. ${ }^{4}$ Even if most studies about the construction of the Brazilian nation, when focusing on temporal dimension analysis, have addressed representations from the country's past, I try to reverse that order. ${ }^{5}$ My objective is to study national projections and their political uses, elaborated by Canon Januário da Cunha Barbosa in the early 1830s, with a special look at how the matter of slavery was measured in this process. This analysis will also help us evaluate the importance of the debate about slavery to define the conditions for the creation of the Brazilian Historic and Geographic Institute (IHGB), which was notoriously the most prestigious educational institution in 19th-century Brazil.

The subject becomes more interesting because Januário da Cunha Barbosa was a versatile and double-faced character, like the god Janus, family patron

\footnotetext{
${ }^{2}$ Antonio Penalves Rocha, "Idéias antiescravistas da ilustração na sociedade brasileira escravista", Revista Brasileira de História, vol. 20, n. 39, São Paulo, 2000, p. 43-79. João Pedro Marques, Os sons do silêncio: Portugal de oitocentos e a abolição do tráfico de escravos, Lisboa, Instituto de Ciências Sociais, 1999. Márcia Berbel; Rafael Marquese; Tâmis Parron, Escravidão e política. Brasil e Cuba, 1790-1850, São Paulo, HUCITEC; Fapesp, 2010. Tâmis Parron, A política da escravidão no Império do Brasil, Rio de Janeiro, Civilização Brasileira, 2011. When this article was almost concluded, I knew the study by Alain El Youseff, Imprensa e escravidão: política e tráfico negreiro no Império do Brasil, Rio de Janeiro, 1822-1850, Dissertação de mestrado, Universidade de São Paulo, São Paulo, 2010.

${ }^{3}$ Considering the nation as an "imagined political community", we will emphasize the study about the forms of creation of Brazilian images and, more specifically, its future. The centrality of the symbolic dimension that is present in this perspective is made stronger by the support of theoretical-methodological references of an intellectual history that is not restricted to an analysis of external and societary elements of the intellectuals' action, but that also tries to handle the analysis of internal elements of the produced texts. About nation, see Benedict Anderson, Nação e consciência nacional, São Paulo, Ática, 1989. About intellectual history, see François Dosse, La Marche des idées: histoire des intelectuels, histoire intelectuelle, Paris, La decouverte, 2003.

${ }^{4}$ More specifically, the matter of nation will be considered here in relation to the complex process of affirmation of a modern regime of historicity, which legitimates and orients collective actions for the future, considering, according to Hartog, that: "Throughout a whole century, which was so remarkably the one of nationalities, national history and writing on behalf of the future have been effectively related".François Hartog, Regimes d'historicité: presentisme et experience du temps, Paris, Seuil, 2003, p. 144. About relationships between past and future, see Reinhard Koselleck, Futuro passado: contribuição à semântica dos tempos históricos, Rio de Janeiro, Contraponto, Editora da PUC-Rio, 2006, p. 305-327.

${ }^{5}$ Valdei Lopes de Araújo, $A$ experiência do tempo: conceitos e narrativas na formação nacional brasileira, 1813-1845, São Paulo, HUCITEC, 2008; Rodrigo Turin, Tempos cruzados: escrita etnográfica e tempo histórico no Brasil oitocentista, Tese de doutorado, Universidade Federal do Rio de Janeiro, Rio de Janeiro, 2009.
} 
of the saint (Saint Januarius, from Gens Januaria) he is named after. ${ }^{6}$ Until his death in 1847 , he worked as an intellectual who united the three main types of intellectuals in Brazil: the clergyman, the illustrated bureaucrat, and the political liberal journalist. ${ }^{7}$ This man lived and considered, through actions and reflections, references from two confronting worlds: the Old Regime and the one of liberal and illuminist values, with their corresponding temporal regimes. We could consider that Januário Barbosa faced the indignation of the Luso-Brazilian Sattelzeit, by struggling to create new cultural references while still using the past ones. This becomes clear in the constant tension between references of a past model to be used in the present, and the effort to create a future that is qualitatively different. Clear tensions in the projection modalities he used will be analyzed here: prophecy and prognosis. ${ }^{8}$

\section{The prophecy of the "vision in Itajuru Peak" and the political use of slave insurrection}

In order to understand how Januário da Cunha Barbosa used the prophecy and his relationship with the subject of slavery, it is important to go back to his political initiation - in 1821 - , when he, together with Gonçalves Ledo, Clemente Pereira, and others, founded the newspaper Revérbero Constitutional Fluminense, which would stand out as one of the great defenders of liberal constitutionalism, and afterwards, of Brazil's independence. Connected to merchants and producers from the Guanabara Bay, in this

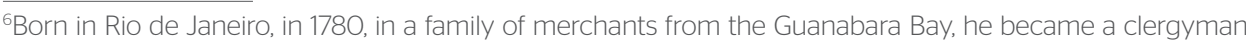
in 1808 and was admitted as one of the orators in the Empire Chapel. However, he was not restricted to this traditional universe: he was also one of the main illustrated, Masonic leaders, professor of Moral Philosophy (after 1814), reader and diffuser of exponents of the illuminist thinking and central character in the encouragement of the first literate academies. From 1833 to 1847, he was an active associate and writer of the journal from the Auxiliary Society of the National Industry, the censor of the Dramatic Conservatory and the founder of Brazilian Historic and Geographic Institute (IHGB). Finally, Canon Januário was a seasoned politician, working as an enthusiast of liberal and constitutional values. More than standing out in public mandates (he only had two mandates as a general deputy, from 1826 to 1829, and from 1845 to 1846), he was inserted in the political struggle as a journalist, writing for journals such as Revérbero Constitucional Fluminense (from 1821 to 1822), Diário Fluminense (from 1830 to 1831), Correio Oficial (from late 1833 to 1837. with interruptions in 1835), A Mutuca Picante (1834), and, perhaps, O Fluminense (from 1835 to 1836). For the story of Januário da Cunha Barbosa, see Paula Porta Santos Fernandes, Elites dirigentes e projeto nacional: a formação de um corpo de funcionários do estado no Brasil, Dissertação de mestrado, Universidade de São Paulo, São Paulo, 2000, p. 165-168; 310-313.

${ }^{7}$ About the open use of the intellectual concept, I follow the suggestion of François Dosse, to whom "the story of intellectuals cannot be limited to an a priori definition of what should be intellectual according to a normative definition. On the contrary, it must remain open to the plurality of these figures that stand out all of the different declinations in order to touch over the keyboards of intellectual expression". François Dosse, La marche des idées: histoire des intelectuels, histoire intelectuelle, Paris, La decouverte, 2003, p. 32. About the type of illustrated bureaucrat, see Paula Porta Santos Fernandes, op cit. About the intellectual type of the political journalist, see Marco Morel, As transformações dos espaços públicos: imprensa, atores políticos e sociabilidades na cidade imperial, 1820-1840, São Paulo, HUCITEC, 2005, p. 167-199. About the intellectual type of the clergymen, ver Maria Renata da Cruz Duran, Ecos do púlpito: oratória sagrada no tempo de D. João VI, São Paulo, Editora da UNESP, 2010.

${ }^{8}$ Reinhard Koselleck. Futuro passado: contribuição à semântica dos tempos históricos, Rio de Janeiro, Contraponto, Editora da PUC-Rio, 2006, p. 21-39.
} 
context, "these liberals defended the exploration of slavery and slave trade", being opposed to the recent British pressure against the Atlantic traffic, therefore against the antislaverism of his political adversary José Bonifácio. ${ }^{9}$ By defending the path to Independence, and this position was only stated during 1822, the group of Canon Januário saw the need to annul some pessimistic projections against it.

Therefore, Revérbero responded to the rumors made by a group of Portuguese deputies to the courts of Lisbon, mobilizing the issue of slavery. With the increasing fear of a slave insurrection in Brazil, Portuguese politicians tried to stop the alternative of political autonomy from the American part of the empire. Revérbero was opposed to that argument, and responded to the Portuguese:

It is clearly very foolish to continue with threats of slave. How can these fools not see that the sublevation of slaves they talk so much about must be more fatal for them [Portuguese] than for us. [...] mulattos and blacks in Brazil are divided into two classes - free and captive - , and the uniformed automatons from Portugal must fear the former; Brazilians have no fear of the latter. ${ }^{10}$

In other words, the threat of a slave rebellion would not prevent the future of Brazil as an independent and constitutional nation. Even if the article was not signed, the view of Canon Januário was in accordance with views that denied the incompatibility between the liberal representative system and slavery. Freedom from slavery guaranteed by the constitution was the only conceivable horizon, under the monarchic rule, that would guarantee order and unity.

However, after eight years, the issue of slavery came back to light, but in a very different context. On April 30, 1830, the Canon became a writer for Diário Fluminense $(D F)$, the official newspaper of the government of D. Pedro I, whom he began to defend from the increasing accusations. As the official journalist of a government that had just (in 1826) signed a treaty with England, committing to repress slave trafficking, Januário began a process of changing positions on slavery. He began to show a growing antislavery stand, which would become the mark of his particular opinion. He slowly ruptured with the previous proslaverism position, as mentioned in one of the issues of $D F$, which has the following criticism against slavery:

Our farmers who are used to harvesting from fertile land, by the work of miserable slaves, a product they are proud of, do not dear to remove them from the old routine, which was imposed by their ancestors, many of them do not even want to hear about the strength of African arms replaced by free arms, and by machines that improve their products, without losing huge funds used in the continuous purchase of Africans. ${ }^{11}$

${ }^{9}$ Cecília Helena Lorenzini de Salles Oliveira, A astúcia liberal: relações de mercado e projetos políticos no Rio de Janeiro, 1820-1824, Bragança Paulista, EdUSF; Icone, 1999, p. 161.

10/bidem, p. 227.

"Diário Fluminense, Rio de Janeiro, 19 de junho, 1830. 
There was a clear criticism of slavery, considered to be a force preventing material progress. The basic argument was the Smithian one, about the lower productivity of slaves compared to that of free men. From the political-economic point of view, the illustrated Canon related slavery to "routine": it would be the result of a negative past that insisted on staying in the present, therefore it had to be suppressed. So, it was the beginning of a process - that would only tend to get stronger - of criticizing slavery, as being incompatible with the future.

However, in that specific context, the matter of political institutions stood out. In that conjuncture, the Canon used the prophecy. In a delicate political moment, when D. Pedro I returned from his trip to Minas Gerais to try and consolidate the adherence of his vassals facing the increasing opposition of moderate and radical liberals, in January 1831, an article was published, which would be known as the "Vision in Itajurú Peak". ${ }^{2}$ The article has been commented by historians such as Gladys Ribeiro and Thomas Flory. ${ }^{13}$ I could identify at least four different versions, and the oldest one (and probably the original one too) was that published in $D F$, the newspaper whose writer was, at the time of publication, Canon Januário da Cunha Barbosa himself. ${ }^{14}$ It is difficult to establish the authorship of this text because it is not signed, but we can safely say it was used by Canon Januário, who published it in the newspaper he wrote for, being responsible for its wide dissemination.

The text has many points in common with the long Portuguese tradition of prophetic dreams, which dates back to the $16^{\text {th }}$ century, resulting from the fusion of variants from the Jewish messianism spread by communities of new Christians or by Franciscan Joachimites. With strong roots in Portuguese culture, this prophetic tradition was found to be present at least until the 1820s, being used in the context of Napoleon's invasion in the Iberian Peninsula. ${ }^{15}$ It is worth remembering that the religious oratory (as the example of Father

\footnotetext{
${ }^{12}$ Anonymous, "Visão achada entre os papéis de um solitário, morto nas imediações de Macacú, vítimas das febres de 1829", Diário Fluminense, 24 de janeiro, 1831.

${ }^{13}$ Gladys Sabina Ribeiro, "Metáforas e ações na longa luta pela liberdade: conflitos entre 'portugueses' e 'homens de cor', corte do Rio de Janeiro, 1827-1834", Tempo, vol. 5, n. 10, 2000, p. 97-117. Thomas Flory, Judge and jury in Imperial Brazil, 1808-1871. Social Control and Political Stability in the New State, Austin; London, University of Texas Press, 1981.

${ }^{14}$ The four found versions would be: 1) an offprint in Lisbon, in 1831. Available from: <http://ler.letras.up.pt/uploads/ ficheiros/5071.pdf>. Accessed on: January 1, 2013; 2) one manuscript and including comments of a second unknown author, currently stored at the National Library of Rio de Janeiro, entitled Aparição extraordinária e inesperada do Velho Venerando ao Rosseiro [sic]: "dialogue between them about the current political status of Brazil, and the extraordinary happenings since April 5, and about the Vision from the Itajurú Peak, found among the papers of a dead solitary in the surroundings of Macacú, victim of the fevers from 1829, and published in the periodicals of that Court in January of the same year, with reflections about the old man, and advice given, as a consequence to all classes of society, for the good and the happiness of Brazil, offered to the concitizens by Rosseiro, after the request of the Old Venerate man". This version, on which the analyses of Gladys Sabina Ribeiro are based on, indicated there had been a version elaborated from the texts "published in the periodicals of this court in January, this year"; 3) a reproduction of the text in O Verdadeiro Patriota, from January 28, 1831, whose microfilm does not contain the last part, where references to transcriptions in other periodicals are usually made; and finally, 4) the version from Diário Fluminense, from January 24, 1831. In it, there is nothing indicating it was published in another newspaper. Since it is the oldest, except for new discoveries, it can be considered as the original version of the text. Even if it is not signed, it was published under the supervision of Januário da Cunha Barbosa, who was then the writer of Diário Fluminense.

${ }^{15}$ Luís Felipe Silvério Lima, O Império dos sonhos: narrativas proféticas, sebastianismo \& messianismo brigantino, São Paulo, Alameda, 2010.
} 
Vieira) was one of the efficient means to disseminate this tradition, and the role played by Canon Januário, as one of the main religious orators in the Joanine court, certainly helps us to understand his presence in Rio de Janeiro in the early 19th century.

However, if there are sequences, there are also points of originality, such as the figure of the messenger chosen for the inspired prophet: the "old man from Itajurú" is a naturalist. In the best style of the illustrated wise man, he goes to the peak of Itajurú to try and understand the cause of revolutions on the surface of the Earth by studying the mountains. However, one common point with the prophetic traditions lies in the fact that the vision of the future is enabled by a dream: tired from the strong heat and exertion of the walk, the old naturalist falls asleep and is awakened by a voice coming from the mountain. Even if the nature of the voice has never been made explicit, it takes on the role of divine illumination, another central element of prophetic tradition. Its reprehension toward the old man means the rupture with the objectives that oriented the Luso-Brazilian illustration. For the voice of the mountain, it was more important to question oneself about the "revolutions of the men" than to understand the secrets of nature.

\section{The final result of the social cataclysm of the \\ black wave would be the disappearance of \\ the entire population, the death of the nation}

Facing the arguments of the old man, claiming that his contemporaries would not be as excited about the radical politics - which would not lead them away from their current paths -, the "voice of the mountain" appeals to the future as being an efficient pedagogical agent, revealed by God. Then begins the description of the vision itself. It is all based on the initial image of "a ship [that] deviated from the shore and, because of that, the whole crowd jumped in joy", screaming "Republic or Death" - , and the echo of the mountain responded: "death, death". This initial act referred to the time when D. Pedro I left Brazil. After that, there was a series of bloody events and, after the attack of landowners and authorities, a process to reverse the social order began. Laws, hierarchy, property, family honor, everything succumbed to the clamors of the mass for equality. Then, a new prophetic movement began after the reversion of the social order, when there was the dissolution of the unit among the agents of the New Order themselves. They were divided in several "magotes" (groups), corresponding to different regions: the ones in the South, the North, the Mountains, and the Shores. On the principle of "Federation", each one tried to be apart from the others. After internal fractioning, there was the invasion of the territory by foreigners, in which the Canon abused the animalizing metaphors: ${ }^{16}$

${ }^{16}$ About its use and sense, see Marco Morel, As transformações dos espaços públicos: imprensa, atores políticos e sociabilidades na cidade imperial, 1820-1840, São Paulo, HUCITEC, 2005, p. 83-98. 
"Leopards", probably symbolizing the British, "Condors", the neighboring Andean republics, and "Vultures", the platinum republics. Being a clear result of the claim for the Federation, the civil war spread among brothers, and the country was submitted to foreigners.

But the high point of the process would correspond to a "black cloud" the old man saw in the North. It is worth mentioning the words from the text:

The cloud was black and similar to a swarm of army ants that leave from the woods to run all over the earth. [...] And the cloud grew, dilating like the torrent of a river that overflows and, very fast it circulated all over the groups and entered the ditches that separated them. It grew, little by little, but never stopped. And the crowd got scared: wanted to be opposed to the black flood that grew more and more, and, decreasing sometimes, like the wave on the beach that returned more violent and covered in foam. Sometimes foam was made of blood. From inside these black waves one could hear noises similar to those in chains that break, raising, at the same time, a voice that said: freedom or death. This voice reverberated more than the sound of the thunder and the echo of the mountains, after repeating it three times, saying: Death, death, death, silence. ${ }^{17}$

It does not seem hard to interpret the cloud of black ants as a clear reference to a slave rebellion. From the author's point of view, they might seem as peaceful as lambs, but, when together, they become threatening to the point of destroying the entire society. So that is what the vision is about, once it is concluded by the metaphor of the Flood, indicating that the black wave never stopped growing, and no spot in the territory was high enough to be safe from it, resulting in the last look: "I looked and all people had disappeared". The final result of the social cataclysm of the black wave would be the disappearance of the entire population, the death of the nation.

Undoubtedly, the vision of the old man from Itajurú mobilized manorial fear of a major slave rebellion, which was presented as a real possibility. But the author's main objective, the central theme, seems to have been the reinforcement of the need for the king as an element that would guarantee the order. The centrality of this political objective becomes apparent once we analyze the editorial line used by Canon Januário in $D F$ in the context of the publication of the vision. It comes at a time when all forces were mobilized by the writer to consolidate the already damaged legitimacy of D. Pedro I, and that was the prevalent line of the newspaper, expressed in several articles. As to slavery or trafficking, they only appeared in the pages of $D F$ as secondary characters. ${ }^{18}$

\footnotetext{
${ }^{17}$ Anonymous, "Visão achada entre os papéis de um solitário", Diário Fluminense, 24 de janeiro de 1831, p. 68. ${ }^{18}$ From the period when Canon Januário was a writer at Diário Fluminense (April 1830 to April 1831), I located a few articles on these issues: June 19, 1830; September 23, 1830; and December 13, 1830. The first has been previously analyzed; the two last ones tried to remember the prohibition of traffic was already valid. They revealed an effort, even if a shy one, to defend the application of the anti-traffic treaty by D. Pedro's government.
} 
The relationship between monarchy and slavery was not often so clear. The first was presented as being necessary, in a proslavery context, to ensure property, social order, constitutional values, and national unity. It is worth mentioning the cause-and-effect relationship subjacent to the narrative of the vision: the suppression of the king, in the beginning of the text, was presented as necessarily leading to the reversion of the social order and to the annulment of the nation by a huge rebellion of slaves, which has been highlighted in the text. The whole text was structured around political arguments defending the character of the king against the social agents not so much identified by their racial composition, but instead, by the defense of political principles of the Republic, Equality, and Federalism, seen as inappropriate for the Brazilian slavery reality, resulting in the indicated social punishments. The major problem would be related to political radicalism, which would trigger the racial conflict — the latter being an involuntary however inescapable consequence of the former. In a certain way, by publishing the text, Januário da Cunha Barbosa used the same strategy with which he had repelled Portuguese deputies to the courts: he frightened landowners and used the presence of slavery as an argument to put obstacles on claims for more political freedom and social equality. Therefore, as to the political sense of its use, the vision of the old man from Itajurú is a case of prophecy with conservative purposes. It did not aim at encouraging changes, but at reinforcing the maintenance of a political and social status quo, breaking with certain modalities of prophecies marked by a utopic character, and looking for the creation of different futures. ${ }^{19}$ There comes the investment on apocalyptic features, without the perspectives of renovation enabled by the millenarist version or even by the notion of palingenesis. ${ }^{20}$

But if this negativity to represent the future was not annulled, it was at least weakened by a hopeful epilogue. In the last lines of the text, right after the old naturalist wakes up from the rest that provided him with the vision, the Skies opened up and he saw "a Matron shining through the rays of eternal glory", who told him:

\begin{abstract}
I have placed before the Throne of God and it protects my children, the Father of my children and the one who sometimes acts like a Mother. So the peace was reestablished in my heart; and I told myself: what I have seen about the Itajurú mountain is not the future, it is a false vision that should not frighten the ones who know how much Heaven protects us and how much prudence can do against the attempts of some madmen who can see little around themselves (author's observation). ${ }^{21}$
\end{abstract}

\footnotetext{
19Luís Felipe Silvério Lima, O Império dos sonhos: narrativas proféticas, sebastianismo \& messianismo brigantino, São Paulo, Alameda, 2010, p. 244-245.

20Jean Delumeau, "Duas leituras diferentes das profecias apocalípticas", In:

Ocidente: 1300-1800 - uma cidade sitiada, São Paulo, Companhia das Letras, 2009.

${ }^{21}$ Anonymous, "Visão achada", Diário Fluminense, 24 de janeiro de 1831, p. 68.
} 
However, in the last sentences, there was still the pertinence of the vision's propagation, which should be written "to be read by those who can meditate and take these lessons that, even in fiction, horrify the ones who know which the infallible consequences of popular mutinies are (author's observation)".

Therefore, the last vision would tend to annul the first one, presented as a "false vision", or with a speech without a realistic epistemological status, a speech "still in fiction": the terms indicate the author's effort to be away from the prophetic model, which, however, he had so well put into practice. It would indicate the reluctance of a period written by a well-known person who gave credit to this archaic modality of future projection, and, however, did not stop mobilizing for the political efficacy he seemed to have with the audience. For this last point, it is worth remembering that instead of being a practice completely abandoned in modern times, the tool of using prophecy as a mean for political action had, after the French Revolution, a blossoming moment, like a distressing counterpart of the revolution era. This happened not only in the Portuguese realm, after Napoleon's invasion, or in Brazilian countryside, but practically all over the West, being an important factor of mass movement, even assuming an important role in Erudite culture, by Romanticism and some organized social movements, such as the British abolitionism. ${ }^{22}$

However, the vision of the old man from Itajurú could not prevent D. Pedro I from being deposed from the throne. Januário da Cunha Barbosa apparently did not use the prophecy again, which does not mean he stopped working on projection. But the political context, as well as his behavior, changed. After movement of deposition, on April 7, 1831, he left DF and, after a brief interval he returned (in the late 1833) to the political journalism as a writer for the government newspaper Diário Oficial, then aligned with the moderate liberals he had fought before. At that time, the issue of slavery again became his primary concern, redefining his expectations.

\section{Among Malês and Haitians: the prognosis of an Atlantic slave rebellion}

After the end of 1833, as a writer for Diário Oficial, Canon Januário was involved in the political struggle by fighting the radical "anarchists" and the caramuru "monsters of retrogradation". ${ }^{23}$ Then, as an agent aligned with moderate liberals in charge, the issue of slavery became the primary concern of Januário Barbosa. However, it was not about an individual movement restricted to the Canon. In the early 1830s, there was intense politicization of issues of slavery and

\footnotetext{
${ }^{22}$ About prophecy and Romanticism, see lan Balfour, The Rhetoric of Romantic Prophecy, Stanford, Stanford University Press, 2002, p. 48. Paul Benichou, "Le temps des prophètes”, In: _.., Romantismes français I, Paris, Gallimard Quarto, 2004. About romantic prophecy and British abolitionism, see Helen Thomas, Romanticism and slave narratives: transatlantic testimonies, Cambridge, Cambridge University Press, 2004.

${ }^{23}$ A Mutuca Picante, 30 de janeiro de 1835.
} 
trafficking, and the Court press was one of their privileged arenas. ${ }^{24}$ Januário Barbosa was part of a group of moderate liberals who prepared a speech and some antislavery measures focusing on defending the end of slave trafficking. However, they did not question the issue of the existing slave property (which they took advantage of), and opposed immediate abolitionist measures. Since the Defender Society of Freedom and National Independence (SDLIN), in Rio de Janeiro, was the main platform for sociability, captained by deputy Evaristo da Veiga, politicians and journalists warned about the increasing retake of the slave trade after $1833 .{ }^{25}$ Canon Januário, in one of the meetings of the Auxiliary Society of the National Industry (SAIN), proposed that the "commission [would]write, urgently, a project of representation for the Government", 26 requesting harsher punishments against slave trafficking, reinforcing the tendency of the movement to put pressure on the authorities to implement the anti-trafficking legislation of 1831. Instead of being created as a formal subterfuge to weaken the British pressure, recent interpretations indicate that the law corresponded to the antislavery effort of some sections from the Brazilian political elite, with an important modification to make slave trade weaker with time. ${ }^{27}$

This antislavery effort did not stop the strong political opposition of some proslavery sectors, connected with traffic, which were experiencing a strong demand of the growing coffee production in Vale do Paraíba. These sectors were captained by the moderate liberal deputy Bernardo Pereira de Vasconcelos. This proslavery movement was one of the causes of the scission among moderate liberals, which would become the "Regresso" conservative movement and the beginning of a systematic policy to defend slavery. ${ }^{28}$ From September 1834 onwards, Vasconcelos initiated a series of attacks in the Chamber, and by using the newspaper $O$ Sete de Abril against Aureliano Coutinho, who was then a moderate liberal "superminister", also associated to SAIN, and who had the two portfolios that were more involved in traffic repression: the justice and the foreigner portfolios. Besides being Vasconcelos' disaffection, Aureliano made efforts to implement law of1831, pressuring local authorities to check on rumors about the secret trade of Africans, and to find and punish smugglers; all of these measures were extensively publicized by Canon Januário himself in Correio Oficial. In September 1834, Aureliano proposed to the Chamber some resources to

\footnotetext{
24Tâmis Parron, A política da escravidão no Império do Brasil, Rio de Janeiro, Civilização Brasileira, 2011, p. 84-103.

${ }^{25} \mathrm{About}$ the reduction and the retake of traffic, see Robert Edgard Conrad, Tumbeiros: o tráfico de escravos para o Brasil, São Paulo, Brasiliense, 1985. About the opposition to traffic, see Marcello Otávio Neri de Campos Basile Rodrigues, O Império em construção: projetos de Brasil e a ação política na corte regencial, Tese de doutorado, Universidade Federal do Rio de Janeiro, Rio de Janeiro, 2004, p. 102-106. Alain El Youseff, Imprensa e escravidão: política e tráfico negreiro no Império do Brasil, Rio de Janeiro, 1822-1850, Dissertação de mestrado, Universidade de São Paulo, São Paulo, 2010, p. 116-127. Robert Edgard Conrad, op cit.

${ }^{26}$ Aurora Fluminense, 10 de março de 1834.

${ }^{27}$ Beatriz Mamigonian; Keila Grinberg, "Para inglês ver? Revisitando a lei de 1831" (dossiê), Estudos Afroasiáticos, ano 29, n. 1-2-3, 2007

${ }^{28}$ Tâmis Parron, op cit., p. 130-134
} 
deport African black people arrested during the repression to trafficking, and also the acceptance of the British proposal that could increase (by accepting the equipment clause) the power of mixed Anglo-Brazilian commissions for a more efficient repression against slave trade, then sabotaged by local authorities and magistrates. ${ }^{29}$ The proposals resulted in the strong opposition of deputy Vasconcelos. In the Chamber, claiming against the attempt to national sovereignty that, in his opinion, represented a deal that submitted Brazilian citizens to British judges, and against the poor use of large public resources to resend the Africans, Vasconcelos defended the proslavery status $q u o$ and tried to annul the initiatives that were contrary to traffic defended by Aureliano. ${ }^{30}$ Arguing for the defense of Brazilian sovereign, he mobilized his own version of the national reason speech, inverting the antislavery meaning mentioned by José Murilo de Carvalho. ${ }^{31}$

In the early 1830s, there was
an intense politicization of issues of
slavery and traffic, and the Court press
was one of its privileged arenas

Vasconcelos also organized an attack by the press, directing its energy and caustic irony on O Sete de Abril. The attack was not only directed at the minister, it fell over the moderates in general and directly reached the group of politicians that was closer to Aureliano Coutinho (called "marrecos"), which was formed by the former butler of the imperial palace, Paulo Barbosa da Silva, by the tutor of the Emperor, Manuel Inácio de Andrade (Marquis of Itanhaém), by the customs director and Aureliano's brother, Saturnino de Sousa e Oliveira, all components of what became known as the "court faction" after the 1840s. ${ }^{32}$ The journalists connected to Vasconcelos called it "sacred cabal", and the definition of the group was indissociable from the slave trafficking issue, being also accused of forming a secret party that controlled the backstage of power to its own benefit, as well as its protégés and British diplomats.

\footnotetext{
${ }^{29}$ Among others, "Ministério da justiça", Correio Oficial, 18 de agosto de 1834. "Ministério dos estrangeiros", Correio Oficial, 25 de setembro de 1834. "Câmara dos senhores deputados. Sessão de 24 de setembro", Correio Oficial, 27 de setembro de 1834.

${ }^{30} \mathrm{O}$ Sete de Abril, 30 de setembro de 1834.

${ }^{31}$ José Murilo de Carvalho, "Escravidão e razão nacional", In: política, Belo Horizonte, Editora da UFMG, 1998.

${ }^{32}$ The little attention given by the Brazilian academic historiography to the "court faction" begins to be overcome by the studies of Julio Bentivoglio. Here, I try to indicate the antislavery policy as one of the possible elements constituting the group's program, which requires further analyses. See Ver Julio Bentivoglio, "Palacianos e aulicismo no Segundo Reinado: a facção áulica de Aureliano Coutinho e os bastidores da corte de D. Pedro II", Esboços, vol. 17, n. 23, 2010, p. 187-222.
} 
Vasconcelos did not spare the more committed moderate liberal journalists who defended minister Aureliano: Evaristo da Veiga, from Aurora Fluminense, and, especially, Canon Januário da Cunha Barbosa. The latter, accused of venality and political opportunism, received, from $O$ Sete de Abril, many humiliating nicknames, such as "shameless Canon" (Cônego sem vergonha), "Friar horsefly" (Frei Mutuca), "Father of bribes" (Padre das molhaduras), the "exorcist" (exorcista), "Father blowfly" (Padre mosca varejeira), "moralist" (moralista), and "mocking Friar" (Frei risota). But the action of Vasconcelos was not restricted to a campaign against court members and Aureliano, being finally triumphant, since this minister was deposed in January 1835 . There was a clear attempt to create a front for the political defense of interests of the traffic and the symbolic legitimation of slavery, as indicated by Tamis Paron and Alain El Youssef. ${ }^{33}$

Therefore, in 1834 diverging political groups were created from the dissolution of the moderate liberal front, and the theme of slave trafficking became one of the cleavage points. As a way to support the initiative led by Vasconcelos, in September 1834, the Mutuca Picante ("Stinging Horsefly"), article written by Canon Januário, adopted the scathing and aggressive tone of the adversary to defend the government. In these pages and in Correio Oficial, Januário defended minister Aureliano and accused Vasconcelos of being a "traitor" of the moderates, and of being a "slaver". ${ }^{4}$

To overcome his adversaries, Januário would use a political strategy that he had used before: using the fear of a slave rebellion. ${ }^{35}$ But, unlike the case of the vision of the Itajurú Peak, this time slavery and slave trafficking appeared as central issues of the fight, which was more than the defense of a public authority. It was about validating the anti-trafficking law of 1831.

Regarding this, Januário published “appalling news" coming from Granada, Trinidad, Monserrat, Saint Kitts, and Dominica, in the British Caribbean in Correio Oficial in November 1834. Besides epidemics, "by a group of Trindade, we know that the cities in these stopovers seemed to be in a state of siege. On August 1,black people, gathered in hundreds and refused to work in most farms. Many were arrested and incarcerated, and it was believed that the island would be immediately placed under the martial law. Even with these measures, the threat of slaves was present because, "In Dominica, the fear was that black people would set the houses of white people on fire while the people were asleep" ${ }^{36}$ Crossing the Atlantic, the news showed common manorial distress and effective impasses in the process of abolishing slavery in British colonies

33Tâmis Parron, A politicica da escravidão no Império do Brasil, Rio de Janeiro, Civilização Brasileira, 2011, p. 130156. Alain El Youseff. Imprensa e escravidão: política e tráfico negreiro no Império do Brasil, Rio de Janeiro, 1822-1850, Dissertação de mestrado, Universidade de São Paulo, São Paulo, 2010, p. 116-127.

${ }^{34}$ Correio Oficial, 06 de outubro de 1834. Correio Oficial, 10 de outubro de 1834. Mutuca Picante, 26 de outubro de 1834

${ }^{35} \mathrm{About}$ the importance and limits of the study of strategies in the history of writings, see Dinah Ribard; Nicolas Schapira (dirs.), On ne peut pas tout réduire à des stratégies:pratiques d'écritures et trajectoires sociales, Paris, PUF, 2013

${ }^{36}$ Correio Oficial, 21 de novembro de 1834 
that, also on August 1, emancipated slaves, thus making them "apprentices" under manorial control until $1838 .{ }^{37}$ However, Canon Januário did not mention abolition. In the following "reflections", he tried to take other lessons from the given experience:

This sad scenario deserves to be seen by our blind farmers who do not want to miss their farming and thus scandalously break one of the most beneficial laws that has been promulgated in Brazil, and prepare, in the near future, for themselves or their children, the same horrors those islanders are suffering. Don't be fooled, our patricians, that each African they put in your farms is a new barrel filled with gunpowder, which has to do terrible explosion; the present interest must not blind you about the terrible future evils. A slave has always been an enemy to his lord; and when he know that, despite the Law, the lord is keeping him from his freedom, he will make desperate efforts for vengeance, and collect the benefit that the law so unfairly denies (author's observation). ${ }^{38}$

Looking at the international slavery context, Januário redefined the relationship between slavery and future in his speech, especially the catastrophic effects of the former over the latter. The experience of the British Caribbean was used to sustain the prognosis that smuggling slaves would create violence and destruction in near future, similar to that prophesied by the old man from Itajurú, who was not mentioned though. At the same time, he repelled the alternative of immediate abolition of slavery that, unlike the gradual path implicit in the law of1831, would lead to turbulence and social chaos. Gradually, Canon Januário redefined his temporal parameters and broke with the condescending posture he defended in the context of Independence, when he saw slavery and the constitution of a free nation as being compatible in the future. Increasingly, slavery and the future of the nation became excluding terms. And the preparation of this future could no longer be postponed; it must begin immediately, with the effective suppression of traffic.

Therefore, the matter of slavery did not only have a central place in the concerns of Januário Barbosa, but it also changed the style of his antislavery writings. It was no longer about highlighting, as he did in 1830, the economic aspect of the low productivity of slaves. The important thing was, for the Canon, to emphasize the threatening aspects of the slavery, presented as a "gunpowder barrel thrown into the mine", major topos of the rhetoric of fear mobilized by Brazilian antislavery faction. The writing style of Brazilian adversaries of trafficking, from the 1830s onward, seems to have been marked by the intensification of the already existing notion of a barbarian slave, on the edge of animosity, enemy of his lord, and a threat to the physical safety

${ }^{37}$ Seymour Drescher, The mighty experiment: free labor versus slavery in British emancipation, Oxford, Oxford University Press, 2002

${ }^{38}$ Correio Oficial, 21 de novembro de 1834 
(not only moral and economic, as stated before) of the society as a whole. ${ }^{39}$ The Canon showed it by considering the Africans were "deadly animals, on whose barbarity their lives (of the buyers and owners) as well as lives of their wives and children depend; enemies that, also due to their numbers, can make them regret their imprudence; and let us hope that some facts would not come to support this hypothesis!" 40

Therefore, Brazilians opposing slavery were against the discourse of North American and European abolitionists, who sometimes appealed to apocalyptic tones, but tended to privilege the sympathy between their interlocutors and slaves, working to emphasize the humanity and the sensitivity of the Africans. ${ }^{41}$ Brazilian antislavers, at that time, tended to a written strategy that inverted the order of priorities. Even if sometimes they wrote about the suffering of the slave, the diffusion of an image marked by negativity and threat prevailed, it was a strange version of negrophobia with antislavery purposes.

This spread of progressive centrality of the slave image as a threat to the safety of the lords had the slave action as an important condition, by the Malê Revolt in Salvador, and this event had a major impact on the ongoing debate. ${ }^{42}$ It happened in the end of January 1835 when Muslim slaves took over the second largest city of the Empire. It promoted a dramatic concreteness to the catastrophic expectations that began to be mobilized by the Canon. As pointed out by historiography, the Malê Revolt spread terror among landowners, who feared it would spread to other cities and to the Court, which led to strong control and violent repression against slaves and emancipation of black men all over the empire. ${ }^{43}$ Even Canon Januário asked for repressive measures against the nagôs in Rio de Janeiro, indicating that his antislaverism

\footnotetext{
${ }^{39} \mathrm{~A}$ similar change can be observed in the speech of another exponent of moderate liberal anti-slaverism: Evaristo da Veiga. Considering his article published in Aurora Fluminense, from May 14, 1834, in which the social threat appeared discreetly as a last argument mobilized in a text concentrating on economic and moral evils of slavery. The arguments in this article can be compared to texts written after the Malê Revolt, in which the topos of the "barrel thrown into the min" became the central argument of his antislavery speeches. About the increasing negativity of the representation of the black person in the 1830 s, see Jaime Rodrigues, O infame comércio. Propostas e experiências no final do tráfico de africanos para o Brasil (1800-1850), Campinas, Editora da UNICAMP; CECULT, 2000, chapter 1. It would be maintained until the 1880 s by Brazilian abolitionists who, unlike their North-American congenerous, were based on a strongly negative representation of the slave as an enemy of the lord and the society, according to the study by Célia Maria Marinho de Azevedo, Abolicionismo: Estados Unidos e Brasil, uma história comparada século XIX, São Paulo, Annablume, 2006, p. 99-146.

${ }^{40} \mathrm{O}$ Fluminense, 16 de dezembro de 1835.

${ }^{41}$ David Brion Davis claims that the diffusion of an antislavery opinion, after the end of the 18th century, can only occur due to a change in the image of the black man, who rescued his full humanity by identifying him as a "manof natural virtue and sensitivity". See David Brion Davis, O problema da escravidão na cultura ocidental, translated by Wanda Caldeira Brant, Rio de Janeiro, Civilização Brasileira, 2001, p. 522-531. About the use of the apocalypse in the British antislavery speech, see Helen Thomas, Romanticism and slave narratives: transatlantic testimonies, Cambridge, Cambridge University Press, 2004, p. 76. About the empathy toward the slave as an antislavery speech strategy of British romantics, see Debbie Lee, Slavery and the romantic imagination, Philadelphia, University of Pennsylvania Press, 2002, p. 33.

42João José Reis, Rebelião escrava no Brasil: a história do levante dos malês em 1835, São Paulo, Companhia das Letras, 2003.

${ }^{43} /$ bidem. Flávio Gomes, História de quilombolas: mocambos e comunidades de senzalas no Rio de Janeiro, século XIX, São Paulo, Companhia das Letras, 2006, p. 213-247.
} 
dispense with the violent control over slaves and free men. ${ }^{44}$ But historiography has little explored the political context of the revolt, marked by the scission of the moderates and the competitive fight between supporters of Vasconcelos and Aureliano, thus neglecting the impact the revolt had on this immediate fight and on the set of the cultural dynamics of the Empire, which we try to prioritize here. ${ }^{45}$

Hardly, due to its dimensions, the Malê rebellion would stop impressing its contemporaries, but certainly the competitive political environment in the Court strengthened the repercussion of the event. Since it happened at the time the proslavery movement of Vasconcelos was growing, it encouraged his adversaries, who tried to address the panic wave that took over the Court against the proslaver deputy. Evaristo da Veiga, by writing polemic articles in Aurora Fluminense, took the leading role in the mobilization of fear and could impose a temporary retreat to his adversary, who had no longer taken proslavery initiatives for about five months. ${ }^{46}$

This proslavery movement was one of the causes of
the scission among moderate liberals, which would
become the conservative "Regresso" movement and
the beginning of a systematic policy to defend slavery

Vasconcelos only brought up the subject again in the end of July 1835 when he requested the annulment of law of 1831, and then in October. At that time, it became clear that Feijó, who had just been named regent, had abandoned what he defended earlier (December, 1834), which was the annulment of the anti-trafficking legislation of 1831, and began suggesting to the Chamber more severe laws against the slave trade and favoring European immigration.

\footnotetext{
44"In this city there are streets where the Nagôs occupy houses in the entire block, and in each house there are 10, 12 and more; they are always together and having meetings, parties, baptisms etc., and nobody controls or watches them". O Fluminense, 03 de novembro de 1835.

${ }^{45} \mathrm{An}$ exception should be made to the dissertation by Alain El Youssef, which I had access to when I had finished this article, and with which I agree in several aspects. It is by far the main study about the political debate about slavery in the Brazilian press from the 19th century. João José Reis analyzed the repercussion of the rebellion in Court newspapers, but his analysis did not focus much on the context of the current political-party struggle, and was basically restricted to Jornal do Commercio e ao Pão de Açúcar. João José Reis, Rebelião escrava no Brasil: a história do levante dos malês em 1835, São Paulo, Companhia das Letras, 2003, p. 509-518.

${ }^{46}$ The strongest action of Vasconcelos in the press was the publication, in O Sete de Abril, on February 10, 1835, of the article Feijó had previously published in Farol Paulistano, on December 24, 1834, favorable to the suppression of the anti-trafficking law of 1831. However, he did not count on the arrival of the news about the Male Rebellion, on the same day, to the Court. After that, his adversary, Evaristo da Veiga, would take the initiative in the writing fight, publishing several articles relating the continuity of traffic with the slave rebellion, thus publically encouraging the panic wave that took over the Court, and blocking, for almost half a year, the pro-traffic offensive that Vasconcelos had been promoting since October, 1834. Only on August 1, 1835, O Sete de Abrilwould publish an article favoring traffic. About the counter-offense of Evaristo, see, among others, Aurora Fluminense, 15 de fevereiro, 22 de fevereiro, 20 de março e 27 de março, all 1835
} 
Then, a new proslavery movement of Vasconcelos began, which not only directly attacked Evaristo da Veiga and governor Feijó, but also argued to prove slavery was compatible with religion and moral, citing ancient, Christian, and modern authors. ${ }^{47}$

As a reaction to this proslavery rearticulation, groups that were closer to the government triggered a new wave of attacks against Vasconcelos and supporters of the slave trafficking, thus using the fear strategy once again. In this sense, the politician from Pará, João Cândido de Deus e Silva, successor of Canon as a writer in Correio Oficial (Januário had left in the end of 1834), continued to identify, in the Malê Revolt, the "black cloud that so melancholically was painted by the old man from Itajurú, in the visions that preceded his death", which "can throw thousands of punishments over the same people who now sleep under its shadow without realizing so many dangers". ${ }^{48}$

Another old terror that was rescued was the one involving a rebellion of Haitian slaves, mobilized as a negative experience to be exorcized. ${ }^{49}$ In this matter, nobody did more than Canon Januário da Cunha Barbosa himself, probable writer for O Fluminense, newspaper founded in October 1835, expressively to defend the government of Feijó. It was used to disseminate the case of the most prevalent political use of Haitianism, and Vasconcelos was the main target. ${ }^{50} \mathrm{O}$ Fluminense tried to identify him as the leader of a larger movement, appealing to conspiracy theories. For that, it used the publication to reduce the responsibility of the newspaper about the publicized information, as if the newspaper was only a mere transmitter of a rumor. However, it would always reinforce it and disseminate it with clear political purposes. So, it was:

\footnotetext{
47"A escravatura”, O Sete de Abril, 31 de outubro de 1835.

${ }^{48}$ Correio Oficial, 13 de novembro de 1835 .

${ }^{49}$ About the uses of Haitianism, see David Geggus (ed.). The Impact of the Haitian Revolution in the Atlantic World, Columbia, University of South Carolina Press, 2001; Flávio Gomes, "Experiências transatlânticas e significados locais: idéias, temores e narrativas em torno do Haiti no Brasil escravista", Tempo, vol. 7, n. 13, p. 146-209, 2002. Alain El Youseff, Imprensa e escravidão: política e tráfico negreiro no Império do Brasil, Rio de Janeiro, 1822-1850. Dissertação de mestrado, Universidade de São Paulo, São Paulo, 2010, p. 128-140.

${ }^{50}$ There is no reference to the identity of the writer of $O$ Fluminense, nor in the studies about the history of the press in Brazil that mention the newspaper (Alain El Youssef talks about it, but considers it to be anonymous), nor in the biographies of Canon Januário. In order to attribute the writing of this publication to him, my conclusions are based on the major postural affinities identified throughout this article, but mainly on the several news published in the newspaper O Sete de Abril. Therefore, O Sete de Abril from December 16, 1835 commented that "Fluminense stays, it is true; however, it is a fool hardly anyone reads, especially after everyone knew its writer was Canon Januário, poor and nowadays old talent"; in O Sete de Abril, January 16, 1836: "Januário, who sells out as a know-it-all for 80 rs, after telling in his Fluminense N 19 that..."; in O Sete de Abril, from June 8, 1836: "the gracious Mr. Canon Januário da Cunha Barbosa, former writer or rented collaborator of Mutuca Picante, Fluminense and other governmental periodicals...". These statements, which attributed the writing of O Fluminense to Canon Januário, were never denied by the pages of this periodical. The fact that the Canon wrote it is more certain than the influence of Vasconcelos about the newspaper $O$ Sete de Abril, whose only existing evidence is the affirmation of his adversaries, however, always denied by the writers of $O$ Sete, which does not stop the contemporary historiography from considering this influence to be accurate.
} 
It is known that, according to public voice (and facts seem to confirm what is said), a major association will be formed for the clandestine introduction of slaves, which [...] has active procurators who not only win for caring for captors, but also publish, in their journals, doctrines that are contrary to the extinction of the Traffic legislation $[s i c]^{51}$, and for that, depositing (worth the truth) 12:000\$000 rs. To whoever else defends the abolition of this law [...]. Preaching the need for slavery in Brazil? Isn't calling utopic the initiatives for this law to be extinguished in favor of the Law that prohibits its introduction belonging to this negrophilous society everyone talks about, or at least encourage its interest based on the infraction of the law? ${ }^{52}$

If Vasconcelos spread the conspiracy ghost of the "sacred cabal" to attack court members and the moderate government; O Fluminense, on the other hand, responded by comparing supporters of the slave trafficking to a "negrophilous society", with all the disqualification and terror the word carried in the immediate post-Malê Revolt period. However, in the following issues of $O$ Fluminense, the writer tried to hypermeasure the actions of the mentioned society, suggesting they were not restricted to the national territory. Again, the publication approached the rumor:

Everyone says a power society has been created in a foreign country, with the purpose of persecuting African slaves that are now all over America, and that several emissaries worked tirelessly on this task, wishing to speed up a benefit that must be slow by bothering us, preparing it with care. We do not know how much credit this rumor deserves, but maybe many movements of these people in some points of Brazil can make this news to be certain. Even though such a company is disguised by the appearance of philanthropy, it becomes horrific for the dangers it exposes the non-African race to, who will have to fight against many evils and suffer the consequences. But be it true or not, it also seems like the sordid greed, through several paths, conspires to involve us in many disgraces, because the introduction of Africans continues to be more active than before it was forbidden by a law that honors the wisdom of who proposed it. ${ }^{53}$

Januário advanced in his strategy of fear and spread a diagnosis marked by a signal of imminent tragedy over the present: Brazil would be threatened by an international plot for the slave rebellion. According to this logic, days after the newspaper $O$ Fluminense also reproduced a story from the Times, showing that some southern states of the United States were still bothered about the distribution of papers filled with "venomous and inflammatory doctrines" by members of abolitionist societies from northern states.

\footnotetext{
${ }^{51}$ The fact here is clearly related to a typo, in which the coherent text with the rest of the note should be "doctrines contrary to the extinction of traffic", without the word "Law".

${ }^{52}$ O Fluminense, 14 de novembro de 1835.

53/dem, 09 de dezembro de 1835.
} 
It indicated that southern citizens invaded the mail and burnt the papers. "The mess came to a point that led to some manifested acts of violence". Even though the situation became calmer, "in the State of Mississippi things became more serious. A conspiracy to emancipate black people had been discovered". ${ }^{54}$ The writer brought the News of anti-abolitionist riots of 1835 in the United States to Brazil as a response to the increasing radicalization of abolitionism in the North, which had an immediate effect. The news from abroad, which had been especially selected and used in an argumentative context being progressively built, reinforced the idea that the mobilization for the freedom of the slaves was not restricted to Bahia nor to the black people, it had continental dimensions and ramifications among different agents (like some abolitionists that were probably white), which exponentially amplified its level of danger, as if the Atlantic was a barrel about to explode.

\section{Januário advanced in his strategy of the fear and disseminated a diagnosis marked by the sign of imminent tragedy over the present}

The importance of both the pieces of news lies in the fact that they clearly presented - in the public domain as a rhetoric strategy with political purposes the same fear of an Atlantic abolitionist articulation that current historiography identified as being present in internal and secret communications, restricted to specific pockets of the government. Tamis Parron showed how, since 1833, a diplomatic Brazilian agent, Eustáquio A. de Melo Santos, in London had been sending reports warning the government about the possible "machinations" motivated by British abolitionists and owners of plantations in the British Caribbean. ${ }^{55}$ Directly connected to the News published in O Fluminense, there is the case, mentioned by Flávio Gomes, of the secret message sent on September 2, 1835, to the Minister of Justice by the diplomatic Brazilian agent in London. It mentioned the case of several abolitionists from the North to cities in the south of the United States. In order to "promote the freedom of slaves, it encouraged rebellions", considering to be "very likely that commissioners from here are sent to the Empire". ${ }^{56}$ The case reported by the diplomatic agent in January was published on December 16 in the same year, aiming at weakening his political adversary and his pro-trafficking policy.

To end this process of political use of Haitianism, putting aside the rumors and any sign of concern about more reliable information, the Canon improved

${ }^{54} \mathrm{O}$ Fluminense, 16 de dezembro de 1835

55Tâmis Parron, A política da escravidão no Império do Brasil, Rio de Janeiro, Civilização Brasileira, 2011, p. 127-128.

${ }^{56}$ Flávio Gomes, História de quilombolas: mocambos e comunidades de senzalas no Rio de Janeiro, século XIX, São Paulo, Companhia das Letras, 2006, p. 218. 
his imaginary gifts and started inventing. He published two letters that had been supposedly intercepted, written by a guy whose characteristics resemble those of Vasconcelos and sent to Boyer, who was then the president of Haiti. In the first and longer letter, the text was:

To my friend and future ally, President Boyer. Rio de Janeiro ....

[...] The disposition of our people today is excellent, even if the frustrated attempts from Bahia tried to let them down. All of my care involves working so that they don't lose hope. [...] thanks to my wisdom, I have been arranging things in a way that some farms endorse with the favor of importing our soldiers. [...] now I can almost safely say that the triumph must be ours, with time and patience. President Boyer and President V....... will enjoy the politics form this rich half of the World, and for us it will be easy, being allied, to end this despicable Nation, which has been the object of my hate for so long.

Several movements have appeared at many points in this province; and since a good result is not likely, they come to excite our people, and have them always working. [...] My future ally, for now it is essential to entertain the idea that it is not possible to give up in the country the importation of Africans, to encourage the prevention among our farmers, to work with the smugglers, and to shout out loud against whoever tries to raise the voice against such a useful trade. ${ }^{57}$

The text listed the elements of the fear discourse that had been elaborated by the Canon. It returned to an argument that was similar to that of the prophecies in the old man from Itajurú, and suggested that the continuity of the "Haitian" policy of Vasconcelos would lead to the destruction of the Brazilian nation. Subjacent to the news, and regardless of sarcasm, there was a prognosis as catastrophic as the prophecy of the old man from Itajurú: that the continuity of the policy of undefined perpetuation of slavery in Brazil would lead to a future marked by the non viability of the nation itself. The compatibility between slavery and national future was fully reverted, and marked the work of the Canon in the context of Independence.

From the Canon's point of view, this distressful feeling about the present and the future became worse because of the shape of political struggle in different regions of the Empire. Especially the bloodiest consequences of the cabanagem, in Pará, strengthened the catastrophic character of the Canon's diagnosis of the present. O Fluminense mentioned the "Batista Campos, Malchers, Vinagres", who "have created a pattern of horror on the thousands of honored Brazilian dead bodies.${ }^{\prime 58}$ Further ahead, reflecting on Pará, Canon Januário encouraged collective fear by confessing that "hairs bristled when we consider the damage [...] [of] a business with so severe consequences". These businesses were not restricted

${ }^{57}$ O Fluminense, 02 de janeiro de 1836.

58"Interior", O Fluminense, 03 de outubro de 1835 
to political fights in the Empire, but they were seen as being indissociable from the slave threat that went all the way to the Court, once, "in Pará, according to the participation of commanders from naval forces, the war is declared against everything that is white; in Bahia, the nagôs work hard to do the same; and who can make sure that is not the intention here and in the other Brazilian provinces?" ${ }^{59}$ For the writer of $O$ Fluminense, nagôs and cabanos were partners of the same "black wave" of Atlantic dimensions, similarly to the vision of the old man from Itajurú, who threatened landowner and "everything that is white".

But even if the Canon presented the country about to fall apart, he was not among those who used the examples of local "anarchy" to put pressure for the revision of institutional reforms of 1834 , in the sense of centralizing the power. Even if Canon Januário had become an expert in calling for increasing respect for laws and authorities, something compatible with the principles of freedom in the order he had always professed and that became even more pertinent as a journalist aligned with the government, we cannot immediately identify him as a supporter of the conservative return. ${ }^{60}$ The demonstrated pieces of evidence, at least for 1834 and 1837, indicate exactly the opposite. Besides the strong opposition he showed against Bernardo de Vasconcelos, the most important articulator of the regressive movement, this distance became even clearer in articles in which he criticized the defense of the creation of a hereditary aristocracy and the revision of decentralizing reforms of 1834, especially the Additional Act, strongly defended by the Canon. ${ }^{61}$

However, all of the efforts made by the Canon to stop the smuggling, by encouraging the fear of a slave rebellion, apparently did not have the desired effect. On the contrary, from the beginning of 1836, the Chamber of Deputies began receiving tons of formal requests from municipal chambers, especially in the coffee production region in Vale do Paraíba, with its ever-growing production, requesting the annulment of the anti-trafficking law of November $7,1831 .{ }^{62}$ Widely publicized by $O$ Sete de Abril, from Vasconcelos, they stated the increasing alignment of landowners with the proslaver policy in the regressive movement. By paraphrasing a statement by David Brion Davis, we could say that in the beginning of the regressive movement in Brazil, greed had overcome fear. ${ }^{63}$ However, terror cannot only be seen as a rhetorical resource, seen as a fake and empty speech. It was rhetorical because it was related to convincing the interlocutors, and it would hardly be of any use if it did not mobilize the anxiety

\footnotetext{
59"Rio de Janeiro", O Fluminense, O3 de outubro de 1835.

${ }^{60}$ About the conservative regressive party, see IImar Rohloff de Mattos, O tempo Saquarema: a formação do Estado Imperial, São Paulo, HUCITEC, 2004; Marcello Basile, "O laboratório da nação: a era regencial (1831-1840)", In: Keila Grinberg; Ricardo Salles (orgs.), O Brasil imperial - volume II, 1831-1870, Rio de Janeiro, Civilização Brasileira, 2009.

${ }^{61}$ O Fluminense, 17 de fevereiro, 13 de abril e 27 de abril de 1836.

${ }^{62}$ Tâmis Parron, A política da escravidão no Império do Brasil, Rio de Janeiro, Civilização Brasileira, 2011, p. 138-142.

${ }^{63}$ Balancing the impact of the fear from the Haitian experience among landowners, Davis considered that "in human life, fear seldom overcomes greed". David Brion Davis, "Impact of French and Haitian Revolutions", In: David Geggus (ed.), The Impact of the Haitian Revolution in the Atlantic World,Columbia, University of South Carolina Press, 2001, p. 5.
} 
that was diffused in society. Even if that anxiety had not been sufficient to stop trafficking, it had different effects on social practices, and implied, among other things, measurements to control slaves and free men by the landowners and governors. ${ }^{64}$ It also had effects on the cultural world, and IHGB, we mentioned here, was one of the initiatives that tried to enable a future free of slavery, and these must be better analyzed.

\section{Final considerations}

The political-intellectual journey of Januário da Cunha Barbosa indicates his active participation in one of the more politicized moments of slavery, and the centrality of this matter for the elaboration of prognoses about the future of the Brazilian nation and the direction of his posterior intellectual activity.

From the mid-1830s onward, as a journalist, Januário composed an alternative conditional prognosis that, according to Koselleck, is characterized by the "clear formation of two possibilities", based on the "constantly present experience of the catastrophe" - in that case, the slave rebellion (Malê or Haitian) — "with the intention of formulating an alternative" ${ }^{65}$ According to the Canon's projections, the first one of these "two possibilities" would be to follow the pro-trafficking policy of Vasconcelos, which would lead to a catastrophic future, marked by a new slave rebellion, similar to the Malê Rebellion, but with possibilities of the success and dimensions of the Haitian experience, which would correspond to the annulment of the Brazilian nation. The second possibility for the future would effectively put an end to trafficking by implementing the law of 1831, thus starting a new strong investment policy in experimentalism for the replacement of slave labor for forms of work that would pretentiously be "free", such as European immigration and Indigenous catechism, and these themes he debated in Correio Oficial and SAIN. ${ }^{66}$ This second possibility, which would slowly diffuse the "mine about to explode" of the Brazilian slavery system, constituted the alternative of future defended by the Canon, corresponding to the definition of a horizon of antislavery expectation for the Brazilian nation, which would then be the base for his subsequent intellectual and political projects.

If the mobilization of the slave rebellion idea did not stop proslaverism and regression to establish in the political field, the work of the cultural universe appeared, to the Canon, as an alternative field of work. With the slow conquest of the political field by Vasconcelos' regressive parties, which would take over the government in 1837, the privileged space of the Canon for

\footnotetext{
${ }^{64}$ Besides the repressive governmental measures from the 1830 s and 1840 s, revealed by Flávio Gomes, eloquent is the case of the landowners from Vassouras, from the central point of the Fluminense coffee zone, which, in 1854, made explicit, in a document, the adopted procedures to annul the constant threat of a slave rebellion. See Flávio Gomes, História de quilombolas: mocambos e comunidades de senzalas no Rio de Janeiro, século XIX, São Paulo, Companhia das Letras, 2006, p. 233-247.

${ }^{65}$ Reinhard Koselleck, "El futuro ignoto y el arte de la prognosis", In: ., Aceleración, prognosis y secularización. Tradução, introdução e notas de Faustino Oncina Coves, Valencia, Pré-textos, 2003, p. 90.

${ }^{66}$ About experimentalism as a future projection modality, without slavery, see Seymour Drescher, The mighty experiment: free labor versus slavery in British emancipation, Oxford, Oxford University Press, 2002, p. 88-89.
} 
these experimentalism modalities would become the universe of intellectual academies, especially SAIN, from where the proposal would come, in 1838, to create IHGB. The institute would become a center for the group of court members, when Aurealino Coutinho took over the vice-presidency. ${ }^{67}$

By coordinating the activities of this institution for almost a decade, the work of Januário would be decisive for the centrality assumed by the indigenous people, seen as a privileged agent to replace slave work, in the reflection of the associates about the past and future of the nation. ${ }^{68}$ Therefore, his work would also mark the increasing Indianism nationalism. Among other features, this is shown in a poem from 1847, dedicated to the recently deceased Januário, by Gonçalves Dias, who had just been integrated to the group of intellectuals in the Court. In it, the young poet praised the prophetic character of the Canon's work: Januário would have made the classic poet Claudian jealous, for the exemplary way he "shows us and the horrific cataclysm". ${ }^{69}$ For the eulogy, the poet from Maranhão demonstrated a connection between the antislavery catastrophic projections of the Canon and the effort of some Romantics of the first generation to use the rhetoric of fear as a way to criticize slavery, as it was made clear in his poem Meditação, as demonstrated in the form of apocalyptic prophecy and written two years earlier, in $1845 .^{70}$ The poetic antislaverism of Gonçalves Dias would be complemented by his work inside the IHGB. However, further analyses are necessary to indicate how much and how this horizon of antislavery expectation marked the intellectual work in the $19^{\text {th }}$ century, and, more specifically, the story elaborated by the IHGB.

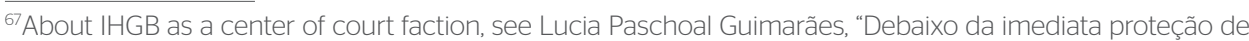
Sua Majestade Imperial: o Instituto Histórico e Geográfico Brasileiro (1838-1889)", Revista do Instituto Histórico e Geográfico Brasileiro, n. 388, 1995, p. 459-613.

${ }^{68} \mathrm{About}$ the reflection regarding the Indigenous people in IHGB, see Kaori Kodama, Os índios no Império do Brasil: a etnografia do IHGB entre as décadas de 1840 e 1860, Rio de Janeiro, FIOCRUZ; São Paulo; EDUSP, 2009, e Rodrigo Turin, Tempos cruzados: escrita etnográfica e tempo histórico no Brasil oitocentista, Tese de doutorado, Universidade Federal do Rio de Janeiro, Rio de Janeiro, 2009.

69"Inveja Claudiano pincel válido, / Que nos retrata o cataclismo horrendo, / Que ele - poeta - não achou no combros / Da ignívoma Tessália". Tenth stanza of the poem "Canto Inaugural. À memória do Cônego Januário da Cunha Barbosa", published in Segundos Cantos. Antônio Gonçalves Dias, Poesias completas, São Paulo, Saraiva, 1957, p. 319

7oWilton José Marques, Gonçalves Dias, o poeta na contramão: literatura e escravidão no Romantismo brasileiro, São Carlos, EdUFSCar, 2010.
} 